\title{
Do Board Characteristics and Corporate Social Responsibility Practices Affects Profitability and Firm Value in the Egyptian Listed Companies?
}

\author{
Dr. Nevine Sobhy Abdel Megeid, PhD, CMA \\ Associate Accounting Professor \\ College of Management and Technology \\ Arab Academy for Science, Technology and Maritime Transport \\ nevinesobhy2@hotmail.com
}

Dr. Mohamed Hassan Abd-Elmageed, PhD

Assistant Accounting Professor

Faculty of Commerce - Ain Shams University

dr.mohamedabdelmageed@bus.asu.edu.eg 


\section{$\underline{\text { Abstract }}$}

Good corporate governance mechanism implementation will consistently strengthen the firm's competitive position, maximizing the firm value, and managing its resources and risks more efficiently, which consequently will lead to strengthen the trust of the firm's stakeholders. Hence, they can operate and grow sustainably

The main aim of this research is to investigate the relationship between corporate governance mechanisms mainly board characteristics (namely: CEO duality, board size and board independence) on firm value using profitability as an intermediate variable in the Egyptian listed non-financial companies. Using a research sample of 45 firms during the period 2015-2020, we run six multiple regression models to test the impact of CEO duality, board independence, board size, gross profit margin, ROA, ROE and Tobin's Q and firm size as a control variables on firm value. Consistent the results reported by many previous researchers, we found that CEOD, Tobin's $Q$ and firm size have a positive significant impact on company's profitability, while board independence has a significant negative relationship with company's profitability. Moreover, Findings shows that corporate social responsibility, Tobin's Q and firm size have a positive significant impact on company's profitability. In addition, the statistical results show that corporate social responsibility, board characteristics as required by corporate governance practices, Tobin's $Q$ and firm size have a positive significant impact on firm value.

The statistical results support the literature and previous scholars indicated for the association between corporate governance mechanism and CSR based on the firm financial performance as a moderator in different causal directions. If governance entities assumed that social responsible decisions enhance the firm's financial performance. In other words, there is a positive relationship between firm financial performance and CSR hence, effective governance mechanisms may promote CSR. This research shows that there is a positive association between CSR and firm value when taking into consideration both stakeholder theory and reputation theory. The statistical results indicate that effective corporate governance mechanisms improve nonfinancial or the social outcomes, namely CSR as the effective monitoring by shareholders and independent boards has a positive impact on CSR.

Keywords: Board Characteristics - Corporate Governance Mechanisms - Corporate Social Responsibility - Profitability - Firm Value - Egypt 


\section{$\underline{\text { Introduction }}$}

In the globalization era, the development in the firms' world more rapidly follows by the increasing in a high competition. Therefore, firm are required to think in a critical and effective way in order to excel in this competition by having an excellent financial performance and a high firm value, in addition continues to increase both of them over time. Increasing the firm value in long-term is one of the most important firm's goals. In go public firms, investor's evaluating to the firm can observed through the firm's stock price movement, which transacted in the stock exchanges (Tobing et al., 2013).

Furthermore, the risks and challenges in the firms' world in increasing rapidly. Therefore, the implementation of good corporate governance becomes very important. Good corporate governance mechanism implementation will consistently strengthen the firm's competitive position, maximizing the firm value, and managing its resources and risks more efficiently, which consequently will lead to strengthen the trust of the firm's stakeholders. Hence, they can operate and grow sustainably (Windah and Andono, 2013).

Moreover, (Scott, 2007) argued that good corporate governance would provide and appropriate incentives for the directors to achieve firm's goals, which meet shareholder interest. In addition, it will also facilitate the effective monitoring processes. Therefore, good corporate governance considered as a guideline for managers to manage their firms in best practices. Through the implementation of corporate governance, directors will require to make financial decisions that can in turn have benefits to stakeholders by increasing the firm value and profitability (Nuswandari, 2009).

However, firms, which are not maximal in implementing good corporate governance, in the end, their investors will abandon them, besides, less appreciated by the public and institution pressure. In addition it may penalized if based on the firm assessment the results proved to violate the law. Therefore good corporate governance needed to build the trust of the public people and the international community and considered as an absolute requirement for the firms to develop well (Effendi, 2016; Odoemelam and Okafor, 2018; Miralles-Quirós et al., 2019; Uyun, 2016; Tumewu and Alexander, 2014; Johansen, 2016; Monciardini, 2016).

Related to corporate governance, corporate social responsibility (CSR) is one of the strategies that help in increasing the firm value by building the right image for the stakeholders. (Wardoyo and Veronica, 2013) argued that CSR disclosure in the annual report will strengthen the firm's image. In addition it will becomes one of the considerations which noticed by investors and potential ones to choose to invest in the firm. That because they will consider that firm provides an image to the community that the firm is no longer 
just pursuing profit but also paying attention to the environment and society, which consequently will increase both firm's value and profitability.

In addition, help to enhance the firm's image in the society and increase the firm's chance to survive and sustain (Thompson and Cowton, 2004; Socoliuc et al., 2018; Ratih, 2011; Retno and Priantinah, 2012; Mukhtaruddin et al., 2019), based on the above literature, and due to the importance of both firm value and profitability in the competition world. The researcher want to empirically examine how the board characteristics such as (board independence, board size and CEO duality), as one of the corporate governance mechanisms and corporate social responsibility practices might affect the firm' profitability and in turn the firm value of the Egyptian listed firms.

\section{$\underline{\text { Research Aim and Questions }}$}

The main aim of this research is to show how the board characteristics (corporate governance mechanisms) and corporate social responsibility practices affect the firm' profitability and in turn the firm value of the Egyptian listed non-financial companies.

The research addresses the following questions?

1. What is the impact of board characteristics on profitability?

2. What is the impact of corporate social responsibility practices on profitability?

3. What is the impact of board characteristics on firm value?

4. What is the impact of corporate social responsibility practices on firm value?

5. What is the impact of profitability on firm value?

6. What is the impact of board characteristics on corporate social responsibility practices?

\section{Literature Review and Hypotheses Development Corporate Governance Mechanisms and Profitability}

\section{Impact of CEO Duality on Profitability}

Agency theory indicate that the CEO duality increases the power of the CEO on the board beside it inhibits the independence plus objectivity between the team of management and the board which in turn leads to negative impact on firm profitability (Jensen et al., 1976; Fama et al.,1993). Consequently, because of the independence lack, the board responsibility in both monitoring and supervising the management will reduce and the presence of interest conflicts will increase. (Haniffa and Hudaib, 2006) investigated the impact of CEO duality on firm's profitability. They used ROA as a proxy to measure the firm profitability. They found that CEO duality has e negative impact on the ROA. This 
means, CEO duality increases the power of the executive one who is more likely to pursue strategies in his own personal interests and not for the firm interest (Tang, 2017). Furthermore, (Duru et al., 2016) investigated the impact of CEO duality on firm profitability. They suggested that suggest that CEO duality has a significant negative impact on the firm profitability. In addition, the non-executive directors play a disciplinary role in the firm which lead to the management' opportunism power limitation (Chen, 2014; Arslan et al., 2014; Kao et al., 2018). Moreover, (Higgs, 2003; Cornett et al., 2008) documented that the separation of the CEO dual role has a significant positive impact on the firm profitability. That because it leads to the prevention in the concentration of both authority and power in one executive person.

In contrast, the stewardship theory and the resource dependence theory (Pfeffer and Salancik, 1978; Donaldson and Davis, 1991) argues that CEO duality has a positive impact on firm profitability. That because the CEO duality solve both power and control separation issues, leading to a positive impact on corporate performance (Amit et al., 2006; Anderson et al., 2003; Palia et al., 2002; Ramdani et al., 2010). As an example (Elsayed, 2007) investigated the impact of CEO duality on firm performance. The results indicated that CEO duality has a mixed and significant impact on the firm profitability which measured by ROA.

In addition, the results suggest that there are some firms, which can get benefits from CEO duality plus having higher firm profitability. That because CEO duality can reduce the cost in a way in which CEO duality eliminates the information transferring process and processing the cost transactions (Goodwin, 2000). As same important, CEO duality can reduce the time in decision-making, which in turn lead to the improvement in the effectiveness of the decision-making process (Peng et al., 2009).

\section{Impact of Board Independence on Profitability}

According to the agency theory, the outside directors required to provide an effective monitoring of firm boards. These outside directors protect stakeholders from managers' opportunistic behavior who may seek for private profits (Kiel and Nicholson 2003). A number of empirical studies explored the association between board independence and profitability. In one from pioneer study, (Klein, 2002) found a negative association between board independence and profitability in the US. Similarly, (Xie et al., 2003) indicate to a similar relationship between these variables both board independence and profitability.

Moreover, by using UK data, (Peasnell et al., 2000) found that in a certain condition, which is, when the pre-managed earnings fall below the previous year's reported earnings, board independence has a positive significant association associated with firm 
reporting practices. Besides, the context of Hong Kong, (Jaggi et al., 2009) indicated to a negative and significant relationship between board independence and profitability. In the Indian context, (Sarkar et al., 2008) found no significant association between board independence and profitability by making a comparable studies between firm's with high independence board and outside directors with the firm's with low one and highly inside structure.

In addition, (Jackling and Johl, 2009) found a positive effect on firm's profitability using a data of Indian firms, in Liu et al. above that some studies documented that the more board independence may provide better overseeing of the overall firm's financial reporting process (Anderson et al., 2004). Moreover, (Beasley, 1996) found that the proportion of board independence on the board is inversely related to a high financial statement fraud. In other words, the mangers of emerging market firms may foresee an easy chance to manipulate the financial statement through inclining in both projects borrowing and investing which is more beneficial to their own self-interest rather than to the firms (Kochhar, 1996; Le et.sl, 2010).

Nevertheless, the firm's with high board independence will be subject to high scrutiny, therefore, will be more rational in making investment decisions from that borrowed money. In addition, the independently monitoring role of the independent board ensures the transparency and effectiveness of the use of debt (Peng, 2004; Mura, 2007). Moreover, the external relationships which other firms may help the managers in enhancing the investments outcomes from borrowed money. Besides, bringing in more outside mangers may in turn facilitate the firms' borrowing (Mizruchi and Stearns, 1994).

\section{Impact of Board Size on Profitability}

Previous scholars indicated that a larger board may leads to an increased in the pool of both knowledge and intellect of directors that can utilized for making a good profitable decisions (Kumar and Singh, 2013; Jensen and Meckling, 1976; Ruigrok et al., 2006; Dalton et al., 1999). In addition, the larger number of managers on the board also enhances the ability of the firm in order to form greater external linkages with other managers in the emerging markets. Moreover, it helps in obtaining favorable and various funding sources to maximize the profitability to investment the firm's projects (Goodstein et al., 1994).

Such previous benefits which gains by a larger number of directors on the firm's board are particularly important in an emerging market context. Especially, where formal capital market is not established and functioned well. Besides, most of firms are highly reliant on the debt financing. Nevertheless, (Jensen, 1993) discussed the rationale for

keeping firm's boards small. That because when board size increases, it becomes more difficult for directors to participate in freely way and objectively mind when dealing with 
board activities. He also argued that managers of the board might also suffer from the biases and behavioral issues as other people. This means that the larger boards become unmanageable and might fail in functioning effectively. In other words, there is a negative relationship between the sizes of firm's boards and firm profitability (Black et al., 2012; Cheng 2008). They also documented that large firm's board might fail to create a high value for their stakeholders. Therefore, the smaller firm's boards can achieve this function efficiently. Moreover, (Ching et al., 2006) argued that if larger firm's boards do not create value for their stakeholders, they might be associated with lower quality of earnings.

\section{Based on the previous illustrated literature, the researchers formed the following hypothesis:}

\section{H1: Board characteristics have significant positive impact on profitability.}

\section{Corporate Social Responsibility Practices and Profitability}

Form the literature, Slack resource theory claims that better financial performance potentially will leads to the enhance in the availability of financial and non-financial resources, which will provide the opportunity to firms in order to invest in the social performance domains, such as the community relations, beside the employee benefits, and the philanthropic donation, or environmental protection. Therefore, if slack resources are available, the allocation of such resources to the social domain will produce better social performance. In other words, that doing well will in turn enable firms in doing well (Seifert, 2004).

Therefore, (Waddock, 1997) argued that better firm's financial performance considered as an indicator to a greater predictor of better firm's social performance. moreover, (Campbell, 2007) indicated that firms' slack resources are essential determinants of CSR activities and documented that firms will be less tend to engage in social responsibilities activities where they are currently relatively have a weak financial performance. Moreover, (Hasan and Habib, 2017) support the previous results by indicating that the lower profitability leads to lower engaged in CER activities.

Furthermore, (Scholtens, 2008) investigated the association between CSR and profitability of US firms. He concluded that there is a significant association between CSR firm's profitability. However, the components of CSR such as community involvement, plus employee relations, and diversity do not have positive relationship with financial performance when taking into the consideration the firm return and risk. Supporting that, (Foote, 2010; Mujahid and Abdullah, 2014) who concluded that there is a positive impact from social activities on the firm financial performance. 
Nevertheless, (Iqbal et al., 2012) showed that CSR has a negative impact on the firm market value. In addition, they argued that the CSR activities do not have any impact on the firm's financial performance. In other words, there is no significant relationship between firm's CSR activities and both firm's profitability and leverage. In the context (Olaroyeke and Nasieku, 2015) documented that CSR activities have a moderate positive impact on the financial performance of manufacturing firms listed on Nigeria Stock Exchange.

In addition, that manufacturing firms engaged in CSR activities not only for seeking to enhancing the profitability but also for other reasons such as better firm image, developing both marketing and advertising strategy, increase employee both satisfaction and fulfillment, besides improving the firm competitive advantage, and enhance the productivity and business opportunities. In other words, the firms use CSR strategies not only to improve their performance but also to strength their legitimacy and reputation

Based on the previous illustrated literature, the researchers formed the following hypothesis:

H2: Corporate social responsibility practices have significant positive impact on profitability.

\section{Corporate Governance Mechanisms and Firm Value}

\section{Impact of CEO Duality on firm value}

CEO duality means that the CEO is also holding the position of the Chairman of the board of directors. According to (Yang and Zhao, 2014) the duality of post of both the CEO and the Chairman of the board of directors considered as one of the most debatable corporate governance issues in recent years. The association between the CEO duality and firm value examined in numerous researches and circumstances, but the results always mixed and inconclusive (Wellalage and Locke, 2011). From one hand, some of the researchers are in the favor of CEO duality in addition came up with the positive association between CEO duality and firm value on other hand other scholars found a negative association between CEO duality and firm value.

Furthermore, and with fast evolving work process dynamics, it is important to have a clear chain of authority and control, and it is not be possible without the role of CEO duality (Gillan, 2006). The previous opinion supported by (Rouf, 2011) who argued in his study that there is a positive association between CEO duality and firm value. On other hand authors such as (Fosberg, 2004; Sanda et al., 2010) indicated that when CEO and chairperson of the board of directors positions are separate, then there will be more valuable prepositions for the firm sake. 
Nevertheless, other scholars documented that the integration of such power in one hand is not the norm of today's work environment. In addition, this power integration will bring negative effects on the firm value especially in the long- run (Combs et al., 2007). Moreover, almost similar result showed by (Agrawal and Chadha, 2005) that the same person should not hold both CEO and chairman of the board of directors.

\section{Impact of Board Independence on Firm Value}

Previous scholars indicated that the simplest way to establish and increase the independence of board in a firm is by finding the presence of the non-executive directors on the firm board (Gallo, 2005). That because the non-executive directors considered as a significant elements and factors in the value creation process of the firm (Choi et al., 2007). Form one hand; there are some researches, which argued the point of view that both board independence and firm value have negative significant relationship.

In other words, the increasing in the outside and non-executive directors will in turn decrease the firm value (Bhagat and Bolton, 2008). Similar results found in the research held by (Dah et al., 2012) which argued that the presence of independent directors will make the firm operation process more completed. In addition and in most of the cases will lead to in of decisions making and thus in turn will negatively affect the firm value because

of the delay of the overall firm's workflow, besides the non-homogeneity with the board of directors members .

On other hand (Chan and li, 2008; Nazir et al., 2009; Dunstan et al., 2011; Rouf, 2011; Khan et al., 2017) argued that there is a positive significant association between both board independent director and firm value. Moreover, the presence of non-executive directors on the firm board might give a positive indicator to the investors and shareholders especially, and stakeholders generally that the firms affairs are prudently monitored and highly controlled. Therefore, that will increase the overall public confidence and subsequently will enhance and add to the firm value (Hassan and Butt, 2009).

Supporting the previous results and according to the agency theory, the large proportion of the independent directors in the firm's board will affect in a positive way the firm value (Ramdani \& Van, 2010). That because the presence of independent directors on the firm's board will insure the effective and timely monitoring and will also safeguard the overall interests of shareholders. In addition, the increase in the independence of the board will lead to on merit the selection of CEO process in order to run the organization (Brickley et al., 1994; Yermack, 1996). 


\section{Impact of Board Size on Firm Value}

One of the main proxies to measure the corporate governance is the board size, which means total number of executive directors on the board. Board of directors has the charge of ensuring the implementation of overall corporate governance practices (Shleifer and Vishn, 1997). According to (Malik et al., 2014) the association between both board size and firm value is still a fundamental issue for scholars. Some researches argued that on average 5 to 16 members are present at the board of the firm (Yasser et al., 2014).

In addition, there are two schools of considerations, the school of the large board and the school of the small size board, each school has its own advantages and criticisms. Moreover, empirical studies results mixed across various countries and different industry dynamics and still it is a matter of investigation of which school of thought should follow in a certain situation (Yang et al., 2009). The imperial results in developing countries found a mix results on the association between the board size as corporate governance mechanism and firm value (Nazir et al., 2009).

From school of small board size point of view, small board size leads to better performance, higher firm value and oversight. That because smaller boards have the more abilities for better communicate, organized coordinate, and help in making effective decisions (Lipton and Lorsch, 1992; Jensen, 1993; Yermack, 1996; Mak et al., 2005). Supporting these previous results (Yasser et al., 2011) suggested that the limited number of executive one in the board of directors has a positive impact on the firm value. Furthermore, (Rouf, 2011) found a negative association between board size and firm value. He justify his results by indicate that small boards results in both efficient and smooth firm's operations.

Nevertheless, other scholars argued that the board size and firm value have a positive relationship (Coleman and Biekpe, 2006). (Van den et al., 2004) argued that resource dependency theory documented that large board size will increases the firm value. That because various and large members might have managerial talent and skills. Therefore, they will perform their duties in an efficient way. There is also a point of view, which argued that large board size has high control on top management. In addition, managers can monitor the management performance and duties, which will eventually increase the firm value (Abdullah et al., 2012).

Based on the previous illustrated literature, the researchers formed the following hypothesis:

H3: Corporate Governance Mechanisms have significant positive impact on firm value. 


\section{Corporate Social Responsibility and Firm Value}

A growing body of studies examined the association between Corporate Social Responsibility (CSR) and firm value. These studies showed mixed results (Orlitzky, 2001; Crisóstomo, et al., 2011; Aupperle, 1985). From both the shareholder and neoclassical economic theory, they considered CSR as a donation from shareholders to stakeholders and a competitive disadvantage compared to their unresponsive peers that might result in lower returns, which in turn affect the firm value (Friedman, 1970). Moreover, CSR may be the outcome of an agency conflict problem between both shareholders and managers (Jensen, 1976). That because managers' own best interests may drive CSR.

However, other scholars based on the stakeholder theory propose that CSR positively affects firm value (Trudel, 2009). However, some argue that there is no relationship between CSR and financial performance (McWilliams, 2000) or, if there is one, that it is too complex to found (Margolis, 2003). More recently, strategy scholars have linked CSR to firm value based on firm reputation theory (Godfrey, 2009; Muller, 2011). They argued that strong reputations for CSR would have the ability in helping to preserve firm value. In other words, there is a positive association between CSR and firm value when taking into consideration both stakeholder theory and reputation theory.

Above that there are some scholars argued that that CSR could use as a strategic method for the stakeholders in order to manage their impact on the firm's overall objectives, which in turn increase the firm value, which mean that there is positive impact from engaging in the CSR on the firm value. In this context, firms can build better associations with their major and influence stakeholders, and then generate positive responses through CSR (Haley, 1992). Moreover, they documented that CSR can not only promote internal employees' perception of firms identity, but also enhance the firm's image and reputation. In addition, increase the value of firm moral capital, which consequently enhance the firm value (Yuanyuan, 2018).

Based on the previous illustrated literature, the researchers formed the following hypothesis:

H4: Corporate social responsibility practices have significant positive impact on firm value.

\section{Firm Value and Financial Performance}

A competitive advantage distinguishes a firm from its peer's competitors. The competitive advantages contribute to higher prices, plus more customers, and brand loyalty. Establishing such an advantage considered as one of the most important goals of any firm. 
In today's emerging markets, it is essential for the firm's success. Without it, the firm will find difficulty in surviving. Competitive advantage maintained to achieve the company's goals, especially the shareholders welfare, which can be achieved by optimizing the firm value, which could reflect by the share price.

(Fatihudin et al., 2018) shows that the increase in firm value usually measured by the increase in the firm's stock price in the market and vice versa. A firm's stock price reflects stakeholder's perception plus firm's ability to earn and grow profits in the future. The vicissitudes of stock prices can influenced by the condition and firm financial position, which often changes every period. A healthy firm is a firm, which has a good financial performance. Therefore, the firm value is high. A high firm value in turn will attract investors to invest in the firm as such there will be an increase in the firm stock prices (Harningsih et al., 2019).

Firm value considered as an economic concept, which reflects the value of the firm success. It is the value which a firm is worthy of at a certain date. Profitability reflects the firm's ability to manage and allocate its internal and external resources. Some scholars indicated that there is a statistically significant impact of profitability on firm value. The higher firm profitability considered as the primary consideration by stakeholders in making their investment decisions. Improved profitability expected to increase the firm value, so that the higher the financial performance, the higher the firm value (Widagdo et al, 2020; Modigliani and Miller, 1958).

\section{Based on the previous illustrated literature, the researchers formed the following hypothesis:}

H5: Profitability has significant impact on firm value.

\section{Corporate Governance Mechanisms and Corporate Social Responsibility Practices}

There have been number of studies, which examine the association between corporate governance mechanism and CSR (Arora and Dharwadkar, 2011; Graves and Waddock, 1994; Johnson and Greening, 1999; Kock et al., 2012). Although agency theory indicated that effective corporate governance mechanism leads to better financial firm outcomes, it is not clear whether this effective corporate governance mechanism also improve nonfinancial or the social outcomes, such as CSR (Eisenhardt, 1989; Jensen \& Meckling, 1976).

Several studies found that effective monitoring by shareholders and independent boards has a positive impact on CSR. In other words, if a strong monitoring mechanism 
leads top managers to take decisions aligned with the stakeholder's long-term interests in turn a high level of monitoring by large stakeholders and independent boards may encourage its firms to engage in CSR activities (Shleifer and Vishny, 1997; Coffey and Fryxell, 1991; Graves and Waddock, 1994; Sethi, 2005). However, others scholars found that effective monitoring mechanisms had a negative impact on CSR. This is because large stakeholders and independence of boards of directors could be more shortsighted to the firm's financial performance (Guthrie and Sokolowsky, 2010; Oh, Chang, and Cheng, 2016; Arora and Dharwadkar, 2011).

Furthermore, previous researches documented inconclusive results for the association between corporate governance mechanism and CSR based on the firm financial performance as a moderator in different causal directions (Marom, 2006; McWilliams and Siegel, 2000). If governance entities assumed that social responsible decisions enhance the firm's financial performance. In other words, there is a positive relationship between firm financial performance and CSR hence, effective governance mechanisms may promote CSR.

In contrast, if governance entities assumed that CSR engagement does not improve the firm financial performance outcomes. In other words, there is a negative relationship between firm financial performance and CSR hence, effective governance mechanisms may discourage CSR since they may consider CSR as an overinvestment and a waste of the firm's valuable resources (Waddock \& Graves, 1997; H. Wang, Choi, \& Li, 2008). As such, it the relationships between corporate governance mechanisms and CSR still inconclusive.

\section{Based on the previous illustrated literature, the researchers formed the following hypothesis:}

H6: Corporate governance mechanisms have significant positive impact on corporate social responsibility Practices.

\section{$\underline{\text { Research Conceptual Framework }}$}

In figure (1), the researchers present the conceptual framework for the research variables and hypotheses to show the relationships between them. The left side shows the corporate social responsibility and the corporate governance mechanisms represented by the board of director's characteristics (namely, CEO duality, board size and board independence) (independent variables), which indicated in the code corporate governance in Egypt and the related literature. The right side shows the value of the firm (dependent variable) and profitability as an intermediate variable. 
Figure (1): Research Conceptual Framework

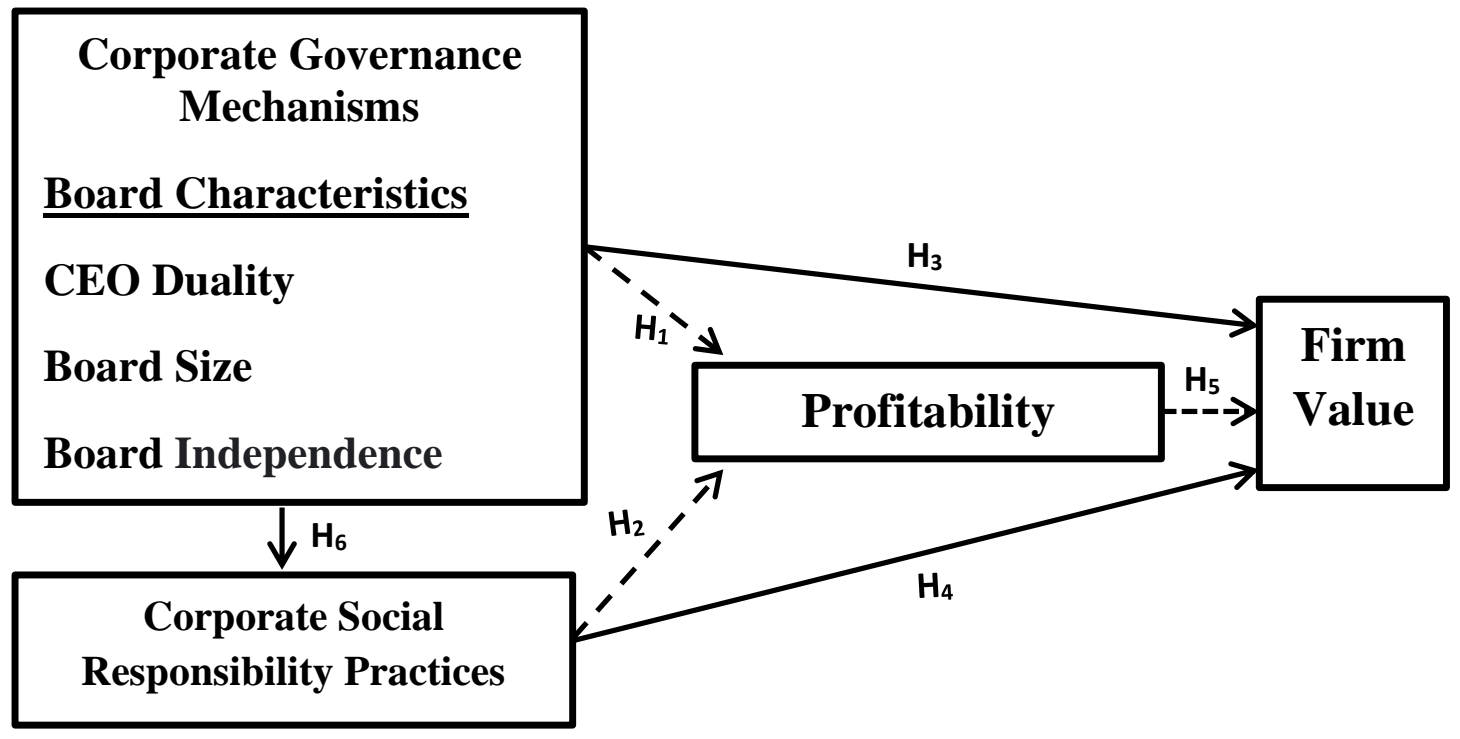

\section{$\underline{\text { Research Methodology }}$}

This research conducted using data from 45 publically listed non-financial companies listed in the Egyptian Stock Exchange (EGX) from the year 2015 till 2020. Financial firms are excluded as they are regulated by different set of corporate governance instructions due to their distinct financial nature. Financial and secondary data were obtained from the financial statements and the published annuals reports disclosed by companies related to their corporate social responsibilities practices and the corporate governance mechanisms that companies apply.

\section{$\underline{\text { Research Variables and Regression Model }}$}

The statistical relationship between board characteristics, corporate social responsibility and firm value in existence of profitability as a mediating variable was tested using the following six multiple regression models:

First regression model, used to examine the impact of board characteristics (corporate governance mechanisms) on profitability.

H1: Board characteristics have significant positive impact on profitability.

$$
\mathbf{R O A}_{\mathrm{it}}=\beta_{0}+\beta_{1} \mathrm{CEOD}_{\mathrm{it}}+\beta_{2} \mathrm{BI}_{\mathrm{it}}+\beta_{3} \mathrm{BS}_{\mathrm{it}}+\beta_{4} \mathrm{TQ}_{\mathrm{it}}+\beta_{5} \mathrm{FS}_{\mathrm{it}}++\varepsilon_{\mathrm{it}}
$$




\section{Where:}

Dependent variable $=$ Profitability $(\mathrm{ROA})$.

$\boldsymbol{\beta}_{0}=$ denotes a constant of the regression equation.

$\boldsymbol{\beta}_{1}, \boldsymbol{\beta}_{2}$ and $\boldsymbol{\beta}_{3}=$ denotes regression coefficient of board characteristics: CEOD, BI and BS (denotes regression coefficient of CEO duality, board independence and board size as indicators for corporate governance mechanisms).

$\boldsymbol{B}_{4}$ and $\boldsymbol{\beta}_{5}=\mathrm{TQ}$ and FS denotes control variables, regression coefficient of Tobin's Q and firm size.

It $=$ Firm $\mathrm{i}$ in period $\mathrm{t}$.

$\mathbf{T}_{\mathbf{i}}=$ Year fixed effect.

$\boldsymbol{\varepsilon}_{\mathrm{it}}=$ Standard error term.

Second regression model, used to examine the impact of corporate social responsibility practices on profitability.

H2: Corporate social responsibility practices have significant positive impact on profitability.

$$
\mathrm{ROA}_{\text {it }}=\beta_{0}+\beta_{1} \mathrm{CSR}_{\mathrm{it}}+\beta_{2} \mathrm{TQ}_{\mathrm{it}}+\beta_{3} \mathrm{FS}_{\mathrm{it}}++\varepsilon_{\mathrm{it}}
$$

\section{Where:}

Dependent variable $=$ Profitability $(\mathrm{ROA})$.

$\boldsymbol{\beta}_{0}=$ denotes a constant of the regression equation.

$\boldsymbol{\beta}_{1}=$ denotes regression coefficient of Corporate Social Responsibility Practices (CSR).

$\boldsymbol{B}_{2}$ and $\boldsymbol{\beta}_{3}=$ TQ and FS denotes control variables, regression coefficient of Tobin's Q and firm size.

It $=$ Firm $\mathrm{i}$ in period $\mathrm{t}$.

$\mathbf{T}_{\mathbf{i}}=$ Year fixed effect.

$\boldsymbol{\varepsilon}_{\mathrm{it}}=$ Standard error term.

Third regression model, used to examine the relationship between board characteristics (corporate governance mechanisms) and firm value.

H3: Corporate governance mechanisms have significant positive impact on firm value.

$$
\mathrm{FV}_{\mathrm{it}}=\boldsymbol{\beta}_{0}+\beta_{1} \mathrm{CEOD}_{\mathrm{it}}+\boldsymbol{\beta}_{2} \mathrm{BI}_{\mathrm{it}}+\boldsymbol{\beta}_{3} \mathrm{BS}_{\mathrm{it}}+\boldsymbol{\beta}_{4} \mathrm{TQ}_{\mathrm{it}}+\boldsymbol{\beta}_{5} \mathrm{FS}_{\mathrm{it}}+\varepsilon_{\mathrm{it}}
$$




\section{Where:}

Dependent variable $=$ Firm Value $(\mathrm{FV})$.

$\boldsymbol{\beta}_{0}=$ denotes a constant of the regression equation.

$\boldsymbol{\beta}_{1}, \boldsymbol{\beta}_{2}$ and $\boldsymbol{\beta}_{3}=$ denotes regression coefficient of board characteristics: CEOD, BI and BS (denotes regression coefficient of CEO duality, board independence and board size as indicators for corporate governance mechanisms).

$\boldsymbol{B}_{4}$ and $\boldsymbol{\beta}_{5}=\mathrm{TQ}$ and FS denotes control variables, regression coefficient of Tobin's Q and firm size.

It $=$ Firm $\mathrm{i}$ in period $\mathrm{t}$.

$\mathbf{T}_{\mathbf{i}}=$ Year fixed effect.

$\boldsymbol{\varepsilon}_{\mathrm{it}}=$ Standard error term .

Fourth regression model, used to examine the relationship between corporate social responsibility and firm value.

H4: Corporate social responsibility practices have significant positive impact on firm value.

$$
\mathbf{F V}_{\mathrm{it}}=\boldsymbol{\beta}_{0}+\beta_{1} \mathrm{CSR}_{\mathrm{it}}+\boldsymbol{\beta}_{2} \mathrm{TQ}_{\mathrm{it}}+\beta_{3} \mathrm{FS}_{\mathrm{it}}+\varepsilon_{\mathrm{it}}
$$

Where:

Dependent variable $=$ Firm Value $(\mathrm{FV})$.

$\boldsymbol{\beta}_{0}=$ denotes a constant of the regression equation.

$\boldsymbol{\beta}_{1}=$ CSR denotes regression coefficient of corporate social responsibility practices.

$\boldsymbol{\beta}_{2}$ and $\boldsymbol{\beta}_{3}=$ TQ and FS denotes control variables, regression coefficient of Tobin's Q and firm size.

It $=$ Firm $\mathrm{i}$ in period $\mathrm{t}$.

$\mathbf{T}_{\mathbf{i}}=$ Year fixed effect.

$\varepsilon_{i t}=$ Standard error term .

Fifth regression model, used to examine the relationship between profitability and firm value.

H5: Profitability has significant impact on firm value.

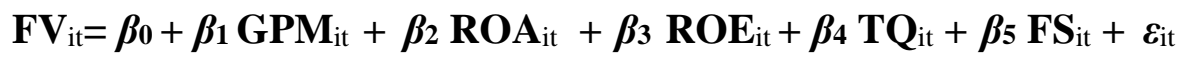




\section{Where:}

Dependent variable $=$ Firm Value $(\mathrm{FV})$.

$\boldsymbol{\beta}_{0}=$ denotes a constant of the regression equation.

$\boldsymbol{\beta}_{1}, \boldsymbol{B}_{2}$ and $\boldsymbol{B}_{3}=$ denotes regression coefficient of GPM, ROA, ROE denotes regression coefficient of gross profit margin, return on assets, return on equity as measures for profitability.

$\boldsymbol{B}_{4}$ and $\boldsymbol{\beta}_{5}=$ TQ and FS denotes control variables, regression coefficient of Tobin's Q and firm size.

It $=$ Firm $\mathrm{i}$ in period $\mathrm{t}$.

$\mathbf{T}_{\mathbf{i}}=$ Year fixed effect.

$\varepsilon_{\text {it }}=$ Standard error term.

Sixth regression model, used to examine the relationship between corporate governance mechanisms and corporate social responsibility practices.

H6: Corporate governance mechanisms have significant positive impact on corporate social responsibility practices.

$$
\mathrm{CSR}_{\mathrm{it}}=\beta_{0}+\beta_{1} \mathrm{CEOD}_{\mathrm{it}}+\beta_{2} \mathrm{BI}_{\mathrm{it}}+\beta_{3} \mathrm{BS}_{\mathrm{it}}+\beta_{4} \mathrm{TQ}_{\mathrm{it}}+\beta_{5} \mathrm{FS}_{\mathrm{it}}+\varepsilon_{\mathrm{it}}
$$

\section{Where:}

Dependent variable $=$ Corporate Social Responsibility Practices (CSR).

$\boldsymbol{\beta}_{0}=$ denotes a constant of the regression equation.

$\boldsymbol{\beta}_{1}, \boldsymbol{\beta}_{2}$ and $\boldsymbol{\beta}_{3}=$ denotes regression coefficient of board characteristics: CEOD, BI and BS (denotes regression coefficient of CEO duality, board independence and board size as indicators for corporate governance mechanisms).

$\boldsymbol{B}_{4}$ and $\boldsymbol{\beta}_{5}=$ TQ and FS denotes control variables, regression coefficient of Tobin's Q and firm size.

It $=$ Firm $\mathrm{i}$ in period $\mathrm{t}$.

The definition and measurement of the independent and dependent variables used in testing the research hypotheses are presented in table (1). 
Table (1): Research Variables, Definitions and Measures

\begin{tabular}{|c|c|c|}
\hline $\begin{array}{c}\text { Dependent and } \\
\text { Independent Variables }\end{array}$ & Definition & Measure \\
\hline \multirow[t]{3}{*}{$\begin{array}{l}\text { Corporate Governance } \\
\text { Mechanisms (CG) } \\
\text { Board Characteristics: } \\
\text { - CEO Duality (CEOD) }\end{array}$} & $\begin{array}{l}\text { CEO Duality occurs when } \\
\text { the same CEO is the chairman of } \\
\text { the board of directors. }\end{array}$ & $\begin{array}{l}\text { To measure the CEO duality } \\
\text { (CD) as an independent } \\
\text { variable, we give value one } \\
\text { (1) when the CEO also } \\
\text { occupies the position of the } \\
\text { chairman and give zero (0) } \\
\text { when the CEO is not the } \\
\text { same person who occupies } \\
\text { the chairman post. }\end{array}$ \\
\hline & $\begin{array}{l}\text { Board Independence, a member } \\
\text { of the board of directors is } \\
\text { considered independent if he is not } \\
\text { an investor in the company and is } \\
\text { not involved in its daily operation } \\
\text { in an executive way. }\end{array}$ & $\begin{array}{l}\text { Board independence ratio } \\
\text { is measured by dividing the } \\
\text { number } \\
\text { of independent directors } \\
\text { (outside / non-executive) by } \\
\text { the total number directors on } \\
\text { the board. }\end{array}$ \\
\hline & $\begin{array}{l}\text { Board Size is the total number of } \\
\text { inside executive and outside non- } \\
\text { executive directors on the board. }\end{array}$ & $\begin{array}{l}\text { Board size (BS) measured as } \\
\text { a small or large based on the } \\
\text { number of directors on the } \\
\text { board. }\end{array}$ \\
\hline $\begin{array}{lr}\text { Corporate } & \text { Social } \\
\text { Responsibility } & \text { practices } \\
(\text { CSR }) & \end{array}$ & $\begin{array}{l}\text { Corporate Social Responsibility } \\
\text { practices are a management } \\
\text { concept whereby companies } \\
\text { integrate social and environmental } \\
\text { concerns in their business } \\
\text { operations and interactions with } \\
\text { their stakeholders. Corporate } \\
\text { responsibility (CR) is about the } \\
\text { impact an organization makes on } \\
\text { society, the environment and the } \\
\text { economy. Having an effective CR } \\
\text { program contributes positively to } \\
\text { all stakeholders as well as adding } \\
\text { value for the organization itself, } \\
\text { and ensures it operates in a } \\
\text { sustainable way. }\end{array}$ & $\begin{array}{l}\text { The Corporate Responsibility } \\
\text { Index (CRI) developed to } \\
\text { enable the quantification of } \\
\text { the qualitative CSR data } \\
\text { obtained from the company } \\
\text { annual reports. } \\
\text { CRI is a management and } \\
\text { benchmarking tool produced } \\
\text { and designed to assist } \\
\text { managers enhance } \\
\text { their CSR performance and to } \\
\text { allow benchmarking of } \\
\text { companies on certain aspects } \\
\text { of CSR. }\end{array}$ \\
\hline Firm Value (FV) & $\begin{array}{l}\text { Firm Value is the market value } \\
\text { that a company is worthy of at a } \\
\text { particular date. }\end{array}$ & $\begin{array}{l}\text { Firm value is measure by } \\
\text { multiplying the number of } \\
\text { outstanding of by the shares } \\
\text { market share price. }\end{array}$ \\
\hline
\end{tabular}




\begin{tabular}{|l|l|l|}
\hline $\begin{array}{l}\text { Gross Profit Margin } \\
\text { (GPM) }\end{array}$ & $\begin{array}{l}\text { Gross Profit Margin Ratio is } \\
\text { used to evaluate the } \\
\text { company's financial position. High } \\
\text { gross profit margin ratio indicates } \\
\text { is a signal effective and efficient } \\
\text { management practices. }\end{array}$ & $\begin{array}{l}\text { Gross profit margin ratio is } \\
\text { measured by dividing net } \\
\text { income by net sales. }\end{array}$ \\
\hline Return on Assets (ROA) & $\begin{array}{l}\text { Return on Assets reflects how a } \\
\text { firm effectively and efficiently } \\
\text { utilizes its available resources. }\end{array}$ & $\begin{array}{l}\text { ROA as a ratio is the net } \\
\text { income divided by average } \\
\text { total assets. }\end{array}$ \\
\hline $\begin{array}{l}\text { Return on Equity } \\
\text { (ROE) }\end{array}$ & $\begin{array}{l}\text { Return on Equity means how the } \\
\text { company' management is able to } \\
\text { generate income from the } \\
\text { investment of shareholders } \\
\text { through increasing productivity } \\
\text { and profits in a sustainable way. }\end{array}$ & $\begin{array}{l}\text { ROE measured as a ratio by } \\
\text { dividing the net income by } \\
\text { average shareholder's equity. }\end{array}$ \\
\hline $\begin{array}{l}\text { Market Performance: } \\
\text { Tobin's Q (TQ) }\end{array}$ & $\begin{array}{l}\text { Tobin's } \text { measures the degree in } \\
\text { which the company generates for } \\
\text { its shareholders. It compares the } \\
\text { book value of its assets to how } \\
\text { much more a company is worth. }\end{array}$ & $\begin{array}{l}\text { Tobin's Q }=\text { Market value of } \\
\text { equity + Book value of short } \\
\text { term liabilities) } \div \text { Book value } \\
\text { of total assets. }\end{array}$ \\
\hline Firm Size (FS) & $\begin{array}{l}\text { The total assets of the company. } \\
\text { Natural logarithm of average } \\
\text { total assets. }\end{array}$ \\
\hline
\end{tabular}

\section{$\underline{\text { Statistical Results and Analysis }}$}

\section{Linear OLS Panel Regression Models}

\section{Model Structure View:}

Typically, data set has a cross sectional observations among different companies and re-sampled at a certain period of time, so a balanced Panel data regression will be most applicable to represent such a linear relationship and the model equation will be written as the following:

$$
\widehat{y}_{i t}=\widehat{\beta}_{0}+\widehat{\beta}_{1} x_{1 t}+\cdots+\widehat{\beta}_{i} x_{i t}+\epsilon_{i t}
$$

\section{Where:}

- $\hat{\beta}_{0}:$ The estimated constant term.

- $\hat{\beta}_{i}$ : The estimated independent Parameter coefficient.

- $y$ : The dependent variable.

- $x$ : The independent variable.

- $i$ : The Country Number. 
- $t$ : Referring to the year.

- $\in$ : Model white noise error.

\section{Steps of constructing a Panel Regression Model:}

- Set the time series variable and the cross-section variable in order to identify the panel regression model.

- Run a pooled Panel Regression and show the model significance result.

- Apply F-test to determine which more significant pooled or fixed model is.

- Apply Breusch-Pagan test to determine which is more significant Pooled or Random model is.

- Apply Hausman test to determine which is more significant Fixed or Random model is.

"In the three tests: F-test, Breusch-Pagan test, and Hausman test if the P-value $<0.05$, accept the alternative hypothesis".

- Pooled OLS: The simplest estimator for panel data is pooled OLS. In most cases this is unlikely to be adequate, but it provides a baseline for comparison with more complex estimators.

- Run normality to make sure that Residuals variance is normal within your model.

- Performing the model diagnostics tests:

\section{- White Stability test for random error variation:}

The regression models and the OLS method are based on several assumptions, including the constancy of homoscedasticity by which the mean should be equal to zero, and if the Heteroscedasticity variation is used, some methods are used to overcome this problem, such as the White test. The null hypothesis is that the model has a problem of random error instability if p-value is greater than 0.05 .

- Normality of residuals:

The residuals of the forecasting model must follow the normal distribution normal distribution in the long run with mean equals zero and variance equals one, a Chi-square test is used for testing the normality with the criteria that if the p-value is greater than 0.05 this means that the residuals are normally distributed.

- Ramsey RESET test for model specification:

This test is used to determine whether the model contains all the appropriate variables and excludes all irrelevant variables to ensure that the model estimated coefficients are not biased. This is done through the Ramsey RESET Test, and 
the decision criterion is to accept the null hypothesis that the study model includes all the appropriate variables P-value was greater than (0.05).

\section{- Variance Inflation Factors:}

Minimum possible value $=1.0$ and the values $>10.0$ may indicate a collinearity problem.

\section{- Goodness of fit tests:}

There are many measures of accuracy and performance of the forecasts. Commonly, the mean absolute error (MAE), root mean squared error (RMSE) and mean absolute percentage error (MAPE) are the most used measures.

- Show the graphical representation of your forecasted values within the standard error of the model.

\section{The six panel models for Estimating the three Multiple Linear Panel}

\section{Regression Equations}

After applying the pooled panel regression for the six models and performing the panel models diagnostics, it's found that the most fitted linear panel model for estimating return on assets (ROA) in model (1) and (2) is the random effect linear regression model, the most fitted linear panel model for estimating firm value (FV) in model (3), (4) and (5) is the random effect linear regression model and also the most fitted linear panel model for estimating corporate social responsibility (CSR) in model (6) is the random effect linear regression model.

The six random effect linear panel models all showed a high level or residuals stability for long run by using white test for Heteroscedasticity and Chi-square test for normality of residuals, Also the six models independent variables and controlling variables have showed a low level of VIF which means that the they don't suffer from multicollinearity, and finally Ramsey Reset test for irrelevant variables showed that all variables are relevant and there is no need for adding or removing variables from any of the three models.

The following six tables (2), (3), (4), (5), (6) and (7) summarize the six linear panel models.

Table (2) shows the statistical results for the first regression model used to examine the impact of board characteristics (corporate governance mechanisms) on profitability. 
Table (2): Random Effect Linear Panel Model for Estimating ROA

\begin{tabular}{|c|c|c|c|c|c|c|}
\hline \multirow{2}{*}{\begin{tabular}{|c|} 
Model \\
Independent variables \\
\end{tabular}} & \multirow{2}{*}{$\begin{array}{c}\begin{array}{c}\text { Random effect } \\
\text { linear Panel }\end{array} \\
\text { Coefficient }\end{array}$} & \multicolumn{2}{|c|}{$\begin{array}{c}\text { Dependent } \\
\text { variable }\end{array}$} & \multicolumn{2}{|c|}{$\boldsymbol{R O A}$} & \multirow[t]{2}{*}{ VIF Test } \\
\hline & & Z-value & p-value & \multicolumn{2}{|c|}{ Significance } & \\
\hline constant & 1.96561 & 8.939 & $<0.0001$ & & & \\
\hline CEOD & 0.672517 & 4.185 & $<0.0001$ & & & 1.048 \\
\hline BI & -0.417810 & -2.246 & 0.0247 & & & 1.003 \\
\hline TQ & 0.00918495 & 2.5760 & 0.0236 & & & 1.050 \\
\hline FS & 0.121965 & 2.3360 & 0.0169 & & & 1.026 \\
\hline \multicolumn{3}{|l|}{ Adjusted R-squared } & \multicolumn{4}{|c|}{$42.86 \%$} \\
\hline \multirow{2}{*}{\multicolumn{3}{|c|}{ Ramsey RESET overall Test }} & \multicolumn{2}{|c|}{ F-test } & \multicolumn{2}{|c|}{$\mathbf{P}$ - value } \\
\hline & & & \multicolumn{2}{|c|}{1.59514} & \multicolumn{2}{|r|}{0.205} \\
\hline \multirow{2}{*}{\multicolumn{2}{|c|}{ Overall test of Heteroscedasticity }} & & \multicolumn{2}{|c|}{ Chi-square } & \multicolumn{2}{|c|}{$\mathbf{P}$ - value } \\
\hline & & & \multicolumn{2}{|c|}{110.511618} & \multicolumn{2}{|c|}{0.0451657} \\
\hline \multirow{2}{*}{ Normality of Residuals } & & & \multicolumn{2}{|c|}{ Chi-square } & \multicolumn{2}{|c|}{$\mathbf{P}$ - value } \\
\hline & & & \multicolumn{2}{|c|}{8.74626} & \multicolumn{2}{|c|}{0.05900} \\
\hline
\end{tabular}

Source: Prepared by the researchers.

\section{From the previous table it is concluded that:}

- The overall Random model is significant with adjusted R-squared value of $42.86 \%$ which means that the significant independent variable and the controlling variables explain the change in the ROA by $42.86 \%$.

- All the independent variables and the controlling variables have significant impact on ROA as all their p-value is less than 0.05.

- CEOD, Tobin's Q and firm size have a positive significant impact on company's profitability, while board independence has a significant negative relationship with company's profitability.

- The overall equation for forecasting the $R O A$ is:

$$
\begin{gathered}
R O A_{i t}=1.96561+0.672517 C E O D_{i t}-0.30 .417810 B I_{i t}+0.00918495 T Q_{I T} \\
+00.121965 F S_{i t}
\end{gathered}
$$


Table (3) shows the statistical results for the second regression model used to examine the impact of corporate social responsibility practices on profitability.

Table (3): Random Effect Linear Panel Model for Estimating ROA

\begin{tabular}{|c|c|c|c|c|c|c|}
\hline \multirow{2}{*}{$\begin{array}{c}\text { Model } \\
\text { Independent variables }\end{array}$} & \multirow{2}{*}{$\begin{array}{c}\text { Random effect } \\
\text { linear Panel } \\
\text { Coefficient }\end{array}$} & \multicolumn{2}{|c|}{$\begin{array}{c}\text { Dependent } \\
\text { variable }\end{array}$} & \multicolumn{2}{|c|}{$\boldsymbol{R O A}$} & \multirow[t]{2}{*}{ VIF Test } \\
\hline & & Z-value & p-value & Signi & ce & \\
\hline constant & 1.65557 & 6.568 & $<0.0001$ & & & \\
\hline CSR & 0.28732 & 7.9784 & $<0.0001$ & & & 1.029 \\
\hline TQ & 0.124671 & 2.7733 & 0.0394 & & & 1.043 \\
\hline FS & 0.140501 & 3.3866 & 0.0279 & & & 1.023 \\
\hline \multicolumn{3}{|l|}{ Adjusted R-squared } & \multicolumn{4}{|c|}{$52.65 \%$} \\
\hline \multirow{2}{*}{\multicolumn{3}{|c|}{ Ramsey RESET overall Test }} & \multicolumn{2}{|c|}{ F-test } & \multicolumn{2}{|c|}{$\mathbf{P}$ - value } \\
\hline & & & \multicolumn{2}{|c|}{1.04406} & \multicolumn{2}{|c|}{0.354} \\
\hline \multirow{2}{*}{\multicolumn{2}{|c|}{ Overall test of Heteroscedasticity }} & & \multicolumn{2}{|c|}{ Chi-square } & \multicolumn{2}{|c|}{$P$ - value } \\
\hline & & & \multicolumn{2}{|c|}{144.329772} & \multicolumn{2}{|c|}{0.026212} \\
\hline \multirow{2}{*}{\multicolumn{2}{|c|}{ Normality of Residuals }} & & \multicolumn{2}{|c|}{ Chi-square } & \multicolumn{2}{|c|}{$P$ - value } \\
\hline & & & \multicolumn{2}{|c|}{2.59966} & \multicolumn{2}{|c|}{0.091100} \\
\hline
\end{tabular}

Source: Prepared by the researchers.

\section{From the previous table it is concluded that:}

- The overall Random model is significant with adjusted R-squared value of $52.65 \%$ which means that the significant independent variable and the controlling variables explain the change in the ROA by $52.65 \%$.

- All the independent variables and the controlling variables have significant impact on ROA as all their p-value is less than 0.05 .

- Corporate social responsibility, Tobin's Q and firm size have a positive significant impact on company's profitability.

- The overall equation for forecasting the $R O A$ is:

$$
R O A_{i t}=1.65557+0.28732 C_{S S}+0.124671 T Q_{I T}+0.140501 F S_{i t}
$$


Table (4) shows the statistical results for the third regression model used to examine the impact of board characteristics (corporate governance mechanisms) on firm value.

Table (4): Random Effect Linear Panel Model for Estimating FV

\begin{tabular}{|c|c|c|c|c|c|c|}
\hline \multirow{2}{*}{\begin{tabular}{|c} 
Model \\
Independent variables
\end{tabular}} & \multirow{2}{*}{$\begin{array}{c}\text { Random effect } \\
\text { linear Panel }\end{array}$} & \multicolumn{2}{|c|}{$\begin{array}{c}\text { Dependent } \\
\text { variable }\end{array}$} & \multicolumn{2}{|c|}{$\boldsymbol{F V}$} & \multirow[t]{2}{*}{ VIF Test } \\
\hline & & Z-value & p-value & \multicolumn{2}{|c|}{ Significance } & \\
\hline constant & 16.1257 & 34.80 & $<0.0001$ & & & \\
\hline CEOD & 0.75606 & 12.9127 & $<0.0001$ & & & 1.048 \\
\hline BI & 0.31836 & 7.801 & $<0.0001$ & & & 1.003 \\
\hline TQ & 0.29687 & 6.451 & $<0.0001$ & & & 1.050 \\
\hline $\mathbf{F S}$ & 0.35556 & 6.880 & $<0.0001$ & & & 1.026 \\
\hline \multicolumn{3}{|l|}{ Adjusted R-squared } & \multicolumn{4}{|c|}{$77.02 \%$} \\
\hline \multirow{2}{*}{\multicolumn{3}{|c|}{ Ramsey RESET overall Test }} & \multicolumn{2}{|c|}{ F-test } & \multicolumn{2}{|c|}{$\mathbf{P}$ - value } \\
\hline & & & 1.24 & 368 & & 0.289 \\
\hline \multirow{2}{*}{\multicolumn{2}{|c|}{ Overall test of Heteroscedasticity }} & & Chi-s & uare & & - value \\
\hline & & & 117.1 & 2281 & & 192881 \\
\hline \multirow{2}{*}{\multicolumn{2}{|c|}{ Normality of Residuals }} & & Chi-s & uare & & - value \\
\hline & & & 112 . & 233 & & .06020 \\
\hline
\end{tabular}

Source: Prepared by the researchers.

\section{From the previous table it is concluded that:}

- The overall Random model is significant with adjusted R-squared value of $77.02 \%$ which means that the significant independent variable and the controlling variables explain the change in the $F V$ by $77.02 \%$.

- All the independent variables and the controlling variables have significant impact on FV as all their p-value is less than 0.05 .

- CEOD, board independence, Tobin's Q and firm size have a positive significant impact on firm value.

- The overall equation for forecasting the $F V$ is:

$$
\begin{gathered}
F V_{i t}=16.1257+0.75606 C E O D_{i t}+0.31836 B_{i t}+0.29687 T Q_{I T} \\
+0.35556 F S_{i t}
\end{gathered}
$$


Table (5) shows the statistical results for the fourth regression model used to examine the impact of corporate social responsibility practices on firm value.

Table (5): Random Effect Linear panel model for estimating FV

\begin{tabular}{|c|c|c|c|c|c|c|}
\hline \multirow{2}{*}{\begin{tabular}{|c|} 
Model \\
Independent variables \\
\end{tabular}} & \multirow{2}{*}{$\begin{array}{c}\text { Random effect } \\
\text { linear Panel }\end{array}$} & \multicolumn{2}{|c|}{$\begin{array}{c}\text { Dependent } \\
\text { variable }\end{array}$} & \multicolumn{2}{|c|}{$\boldsymbol{F V}$} & \multirow[t]{2}{*}{ VIF Test } \\
\hline & & Z-value & p-value & Signi & ice & \\
\hline constant & 16.2243 & 36.60 & $<0.0001$ & & & \\
\hline CSR & 0.110775 & 7.035 & $<0.0001$ & & & 1.029 \\
\hline TQ & 0.291309 & 11.438 & $<0.0001$ & & & 1.043 \\
\hline $\mathbf{F S}$ & 0.378822 & 11.718 & $<0.0001$ & & & 1.023 \\
\hline \multicolumn{3}{|l|}{ Adjusted R-squared } & \multicolumn{4}{|c|}{$81.46 \%$} \\
\hline \multirow{2}{*}{\multicolumn{3}{|c|}{ Ramsey RESET overall Test }} & \multicolumn{2}{|c|}{ F-test } & \multicolumn{2}{|c|}{$\mathbf{P}$ - value } \\
\hline & & & 1.3 & & & 0.264 \\
\hline \multirow{2}{*}{\multicolumn{2}{|c|}{ Overall test of Heteroscedasticity }} & & Chi-s & uare & & - value \\
\hline & & & 110.9 & 5047 & & 203688 \\
\hline \multirow{2}{*}{ Normality of Residuals } & & & Chi-s & |uare & & - value \\
\hline & & & 2.1 & & & .05070 \\
\hline
\end{tabular}

Source: Prepared by the researchers.

\section{From the previous table it is concluded that:}

- The overall Random model is significant with adjusted R-squared value of $81.46 \%$ which means that the significant independent variable and the controlling variables explain the change in the $F V$ by $81.46 \%$.

- All the independent variables and the controlling variables have significant impact on FV as all their p-value is less than 0.05 .

- Corporate social responsibility, Tobin's Q and firm size have a positive significant impact on firm value.

- The overall equation for forecasting the $F V$ is:

$$
F V_{i t}=16.2243+0.110775 C S R_{i t}+0.291309 T Q_{I T}+0.378822 F S_{i t}
$$


Table (6) shows the statistical results for the fifth regression model used to examine the impact of profitability on firm value.

Table (6): Random Effect Linear Panel Model for Estimating FV

\begin{tabular}{|c|c|c|c|c|c|c|}
\hline \multirow{2}{*}{\begin{tabular}{|c|} 
Model \\
Independent variables
\end{tabular}} & \multirow{2}{*}{$\begin{array}{c}\begin{array}{c}\text { Random effect } \\
\text { linear Panel }\end{array} \\
\text { Coefficient }\end{array}$} & \multicolumn{2}{|c|}{$\begin{array}{c}\text { Dependent } \\
\text { variable }\end{array}$} & \multicolumn{2}{|c|}{$F V$} & \multirow{2}{*}{$\begin{array}{l}\text { VIF } \\
\text { Test }\end{array}$} \\
\hline & & Z-value & $p$-value & \multicolumn{2}{|c|}{ Significance } & \\
\hline constant & 12.1105 & 5.573 & $<0.0001$ & & & \\
\hline GPM & 0.272625 & 2.053 & 0.0401 & & & 1.128 \\
\hline$\overline{\text { ROA }}$ & 0.177042 & 2.307 & 0.0337 & & & 4.369 \\
\hline ROE & 0.436375 & 3.264 & 0.0040 & & & 4.568 \\
\hline TQ & 0.357811 & 3.791 & 0.0032 & & & 1.020 \\
\hline FS & 0.305319 & 7.597 & $<0.0001$ & & & 1.022 \\
\hline \multicolumn{3}{|l|}{ Adjusted R-squared } & \multicolumn{4}{|c|}{$62.99 \%$} \\
\hline \multirow{2}{*}{\multicolumn{3}{|c|}{ Ramsey RESET overall Test }} & \multicolumn{2}{|c|}{ F-test } & \multicolumn{2}{|c|}{$\overline{P \text {-value }}$} \\
\hline & & & \multicolumn{2}{|c|}{0.876498} & \multicolumn{2}{|c|}{0.418} \\
\hline \multirow{2}{*}{\multicolumn{2}{|c|}{ Overall test of Heteroscedasticity }} & & Chi-s & quare & & value \\
\hline & & & 33.2 & 9051 & & 31276 \\
\hline \multirow{2}{*}{ Normality of Residuals } & & & Chi-s & quare & & value \\
\hline & & & \multicolumn{2}{|c|}{3.1077} & & 7910 \\
\hline
\end{tabular}

Source: Prepared by the researchers.

\section{From the previous table it is concluded that:}

- The overall Random model is significant with adjusted R-squared value of $62.99 \%$ which means that the significant independent variable and the controlling variables explain the change in the $F V$ by $62.99 \%$.

- All the independent variables and the controlling variables have significant impact on FV as all their p-value is less than 0.05.

- All profitability indicators (namely, gross profit margin, return on assets and return on equity) and also the control variables: Tobin's $Q$ and firm size have a positive significant impact on firm value.

- The overall equation for forecasting the $F V$ is:

$$
\begin{gathered}
F V_{i t}=12.1105+0.272625 G P M_{i t}+0.177042 R O A_{i t}+0.436375 R O E_{I T} \\
+0.357811 Q_{i t}+0.305319 F S_{i t}
\end{gathered}
$$


Table (7) shows the statistical results for the sixth regression model used to examine the impact of corporate governance mechanisms on corporate social responsibility practices.

Table (7): Random Effect Linear Panel Model for Estimating CSR

\begin{tabular}{|c|c|c|c|c|c|c|}
\hline \multirow{2}{*}{\begin{tabular}{|c|} 
Model \\
Independent variables \\
\end{tabular}} & \multirow{2}{*}{\begin{tabular}{|c|}
$\begin{array}{c}\text { Random effect } \\
\text { linear Panel }\end{array}$ \\
Coefficient \\
\end{tabular}} & \multicolumn{2}{|c|}{$\begin{array}{c}\text { Dependent } \\
\text { variable }\end{array}$} & \multicolumn{2}{|c|}{ CSR } & \multirow[t]{2}{*}{ VIF Test } \\
\hline & & Z-value & p-value & \multicolumn{2}{|c|}{ Significance } & \\
\hline constant & 0.715800 & 10.86 & $<0.0001$ & & & \\
\hline CEOD & 0.586362 & 6.123 & $<0.0001$ & & & 1.048 \\
\hline BI & 0.495967 & 9.337 & $<0.0001$ & & & 1.003 \\
\hline TQ & 0.122157 & 2.691 & 0.0071 & & & 1.050 \\
\hline $\mathbf{F S}$ & 0.585603 & 2.554 & 0.0396 & & & 1.026 \\
\hline \multicolumn{3}{|l|}{ Adjusted R-squared } & \multicolumn{4}{|c|}{$46.15 \%$} \\
\hline \multirow{2}{*}{\multicolumn{3}{|c|}{ Ramsey RESET overall Test }} & \multicolumn{2}{|c|}{ F-test } & \multicolumn{2}{|c|}{$P$ - value } \\
\hline & & & \multicolumn{2}{|c|}{1.10415} & \multicolumn{2}{|c|}{0.333} \\
\hline \multirow{2}{*}{\multicolumn{3}{|c|}{ Overall test of Heteroscedasticity }} & \multicolumn{2}{|c|}{ Chi-square } & \multicolumn{2}{|c|}{$\overline{P \text {-value }}$} \\
\hline & & & \multicolumn{2}{|c|}{112.996431} & \multicolumn{2}{|c|}{0.048087} \\
\hline \multirow{2}{*}{\multicolumn{3}{|c|}{ Normality of Residuals }} & \multirow{2}{*}{\multicolumn{2}{|c|}{ Chi-square }} & \multicolumn{2}{|c|}{$P$ - value } \\
\hline & & & & 8.12330 & \multicolumn{2}{|c|}{0.05001} \\
\hline
\end{tabular}

Source: Prepared by the researchers.

\section{From the previous table it is concluded that:}

- The overall Random model is significant with adjusted R-squared value of $46.15 \%$ which means that the significant independent variable and the controlling variables explain the change in the CSR by $46.15 \%$.

- All the independent variables and the controlling variables have significant impact on CSR as all their p-value is less than 0.05 .

- CEOD, board independence, Tobin's Q and firm size have a positive significant impact on corporate social responsibility.

- The overall equation for forecasting the $C S R$ is:

$$
\begin{gathered}
C S R_{i t}=0.715800+0.586362 C E O D_{i t}+0.495967 B I_{i t}+0.122157 T Q_{I T} \\
+0.585603 F S_{i t}
\end{gathered}
$$


The forecasting charts of the six linear panel models are presented in figure (2).

Figure (2): The Forecasting Charts of the Six Linear Panel Models

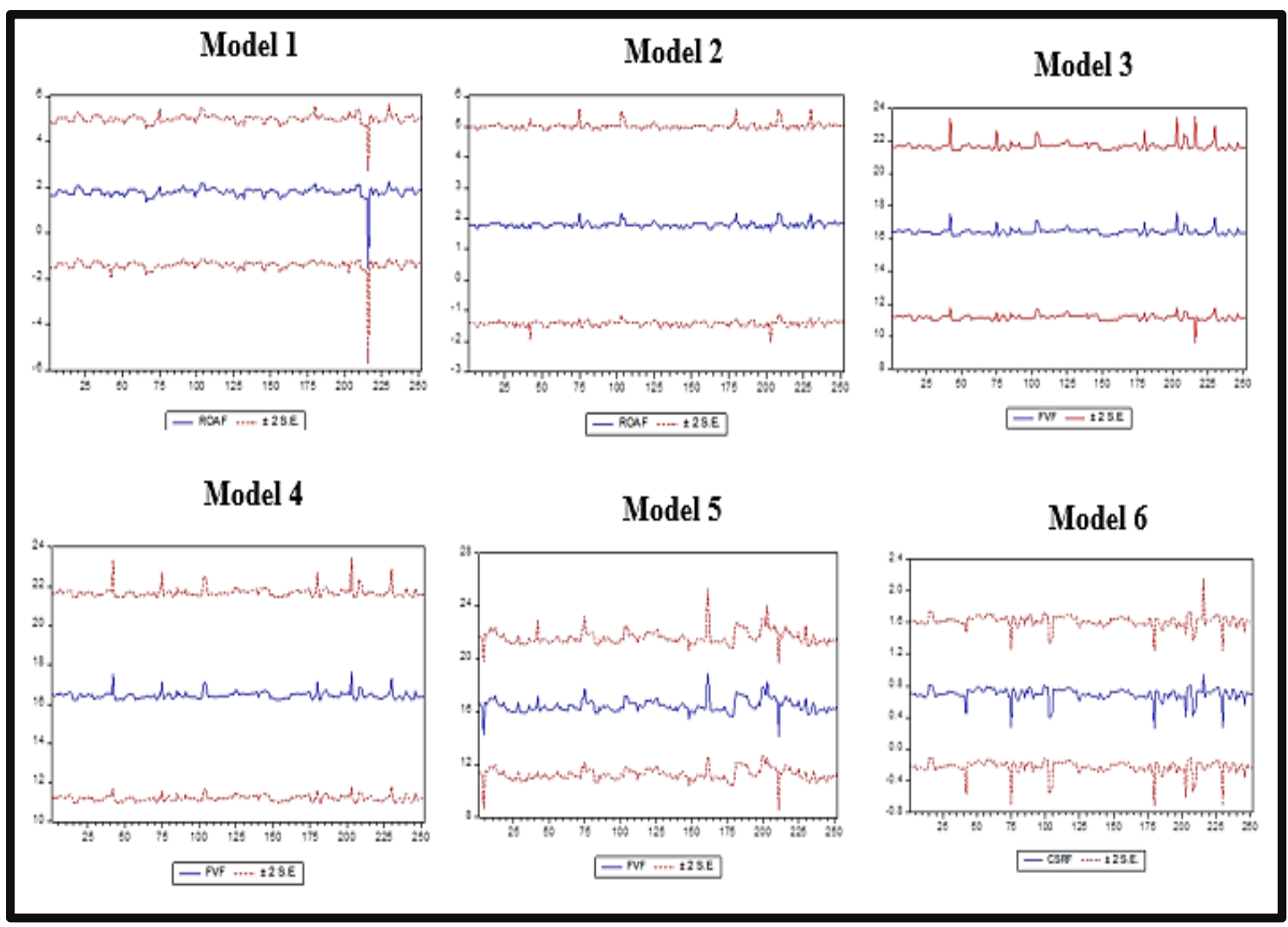

Source: E-views software. 
Table (8) summarizes the results of the six linear panel regression models and their hypotheses.

Table (8): Summary Table

\begin{tabular}{|c|c|c|c|c|}
\hline \multicolumn{5}{|c|}{ Model } \\
\hline \multirow{4}{*}{$\begin{array}{l}\text { Overall } \\
\text { Hypothesis }\end{array}$} & \multirow{3}{*}{ Significance } & First & Second & Third \\
\hline & & $\begin{array}{l}\text { Accept the } \\
\text { Hypothesis }\end{array}$ & $\begin{array}{l}\text { Accept the } \\
\text { Hypothesis }\end{array}$ & $\begin{array}{l}\text { Accept the } \\
\text { Hypothesis }\end{array}$ \\
\hline & & $\begin{array}{l}\text { Significant } \\
\text { Relationship } \\
\text { exists } \\
\end{array}$ & $\begin{array}{c}\text { Significant } \\
\text { Relationship } \\
\text { exists } \\
\end{array}$ & $\begin{array}{c}\text { Significant } \\
\text { Relationship exists }\end{array}$ \\
\hline & $\begin{array}{l}\text { Alternative } \\
\text { Hypothesis }\end{array}$ & $\begin{array}{c}\text { Accept H1: } \\
\text { Board } \\
\text { characteristics } \\
\text { have significant } \\
\text { positive impact } \\
\text { on profitability. }\end{array}$ & $\begin{array}{c}\text { Accept } \mathbf{H}_{2} \text { : } \\
\text { Corporate social } \\
\text { responsibility } \\
\text { practices have } \\
\text { significant } \\
\text { positive impact } \\
\text { on profitability. }\end{array}$ & $\begin{array}{c}\text { Accept H3: } \\
\text { Corporate } \\
\text { governance } \\
\text { mechanisms have } \\
\text { significant positive } \\
\text { impact on firm } \\
\text { value. }\end{array}$ \\
\hline \multirow[b]{4}{*}{$\begin{array}{l}\text { Overall } \\
\text { Hypothesis }\end{array}$} & \multirow{3}{*}{ Significance } & Forth & Fifth & Sixth \\
\hline & & $\begin{array}{l}\text { Accept the } \\
\text { Hypothesis }\end{array}$ & $\begin{array}{l}\text { Accept the } \\
\text { Hypothesis }\end{array}$ & $\begin{array}{l}\text { Accept the } \\
\text { Hypothesis }\end{array}$ \\
\hline & & $\begin{array}{l}\text { Significant } \\
\text { Relationship } \\
\text { exists } \\
\end{array}$ & $\begin{array}{l}\text { Significant } \\
\text { Relationship } \\
\text { exists } \\
\end{array}$ & $\begin{array}{c}\text { Significant } \\
\text { Relationship exists }\end{array}$ \\
\hline & $\begin{array}{l}\text { Alternative } \\
\text { Hypothesis }\end{array}$ & $\begin{array}{l}\text { Accept } \mathbf{H}_{4} \text { : } \\
\text { Corporate } \\
\text { social } \\
\text { responsibility } \\
\text { practices have } \\
\text { significant } \\
\text { positive impact } \\
\text { on firm value. }\end{array}$ & $\begin{array}{c}\text { Accept H5: } \\
\text { Profitability has } \\
\text { significant } \\
\text { impact on firm } \\
\text { value. }\end{array}$ & $\begin{array}{c}\text { Accept H6: } \\
\text { Corporate } \\
\text { governance } \\
\text { mechanisms have } \\
\text { significant positive } \\
\text { impact on } \\
\text { corporate social } \\
\text { responsibility } \\
\text { Practices. } \\
\end{array}$ \\
\hline
\end{tabular}

Source: Prepared by the researchers. 


\section{$\underline{\text { Conclusion }}$}

This research examines the relationship between corporate governance mechanisms mainly board characteristics (namely: CEO duality, board size and board independence) on firm value using profitability as an intermediate variable in the Egyptian listed nonfinancial companies. Using a research sample of 45 firms during the period 2015-2020, we run six multiple regression models to test the impact of CEO duality, board independence, board size, gross profit margin, ROA, ROE and Tobin's Q and firm size as a control variables on firm value. Consistent the results reported by many previous researchers, we found that CEOD, Tobin's Q and firm size have a positive significant impact on company's profitability, while board independence has a significant negative relationship with company's profitability. Moreover, Findings shows that corporate social responsibility, Tobin's Q and firm size have a positive significant impact on company's profitability. In addition, the statistical results show that corporate social responsibility, board characteristics as required by corporate governance practices, Tobin's $Q$ and firm size have a positive significant impact on firm value.

Furthermore, all profitability indicators (namely, gross profit margin, return on assets and return on equity) and also the control variables: Tobin's Q and firm size have a positive significant impact on firm value. Finally, statistical results shows that CEOD, board independence, Tobin's $Q$ and firm size have a positive significant impact on corporate social responsibility.

In summary, related to corporate governance, corporate social responsibility (CSR) is one of the strategies that help in increasing the firm value by building the right image for the stakeholders. CSR disclosure in the annual report will strengthen the firm's image. In addition it will becomes one of the considerations which noticed by investors and potential ones to choose to invest in the firm. That because they will consider that firm provides an image to the community that the firm is no longer just pursuing profit but also paying attention to the environment and society, which consequently will increase both firm's value and profitability.

\section{$\underline{\text { References }}$}

1. Agrawal, A., \& Chadha, S. (2005). "Corporate Governance and Accounting Scandals". Journal of Law and Economics, 48(2), 371-406.

2. Amit, R., Villalonga, B., (2006), "How do Family Ownership, Control and Management affect Firm Value?’. Journal Financial Economics, 80, 385-417.

3. Arora, P., \& Dharwadkar, R. 2011. "Corporate Governance and Corporate Social Responsibility (CSR): The Moderating Roles of Attainment Discrepancy and Organization Slack”. Corporate Governance: An International Review, 19, 136-152. 
4. Arslan, M., Zaman, R., Malik, R. K., Mehmood A., (2014). "Impact of CEO Duality and Audit Committee on Firm Performance: A Study of Oil \& Gas Listed Firms of Pakistan.". Research Journal of Finance and Accounting, 5(17), 151-156.

5. Aupperle, K. E., Carroll, A. B., \& Hatfield, J. D. (1985). "An empirical examination of the relationship between corporate social responsibility and profitability". Academy of management Journal, 28(2), 446-463.

6. Beasley, M., (1996). "An Empirical Analysis of the Relation between the Board of Director Composition and Financial Statement Fraud". Accounting Review, 71, 443465.

7. Bhagat, S., \& Bolton, B. (2008). "Corporate Governance and Firm Performance". Journal of Corporate Finance, 14(3), 257-273.

8. Campbell, J. L. (2007). "Why would Corporations Behave in Socially Responsible Ways? An Institutional Theory of Corporate Social Responsibility". Academic Management Review, 32, 948-967.

9. Chan, K. C., \& Li, J. (2008). "Audit Committee and Firm Value: Evidence on Outside Top Executives as Expert-Independent Directors". Corporate Governance: An International Review, 16(1), 16-31.

10. Chen, H., (2014). "CEO Duality and Firm Performance: An Empirical Study of EU Listed Firms", $3^{\text {rd }}$ IBA Bachelor Thesis Conference, Enschede, the Netherlands.

11. Choi, J. J., Park, S. W., \& Yoo, S. S. (2007). "The Value of Outside Directors: Evidence from Corporate Governance Reform in Korea". Journal of Financial and Quantitative Analysis, 42(04), 941-962.

12. Coffey, B. S., \& Fryxell, G. E. (1991). "Institutional Ownership of Stock and Dimensions of Corporate Social Performance: An Empirical Examination”. Journal of Business Ethics, 10, 437-444.

13. Combs, J. G., Ketchen, D. J., Perryman, A. A., \& Donahue, M. S. (2007). "The Moderating Effect of CEO Power on the Board Composition-Firm Performance Relationship". Journal of Management Studies, 44(8), 1299-1323.

14. Cornett, M.M., Marcus, A.J., Tehranian, H. (2008). "Corporate Governance and Payfor-Performance: The Impact of Earnings Management”. Journal of Financial Economics, 87(2), 357-373.

15. Crisóstomo, V. L., de Souza Freire, F., \& De Vasconcellos, F. C. (2011). "Corporate Social Responsibility, Firm Value and Financial Performance in Brazil”. Social Responsibility Journal, 54(3), 132-150.

16. Donaldson, L., J. H. Davis (1991), "Stewardship Theory or Agency Theory: CEO Governance and Shareholder Returns". Australian Journal of Management, 16, 49-64.

17. Dunstan, K. L., Keeper, T., Truong, T. P., \& Van Zijl, T. (2011). "The Influence of Board Structure on the Value of NZX Listed Firms and its Association with Growth Options". Available at SSRN 2028629. 
18. Duru, A., Iyengar, R. J., Zampelli, E.M., (2016). "The Dynamic Relationship between CEO Duality and Firm Performance: The Moderating Role of Board Independence". Journal of Business Research, 69, 4269-4277.

19. Effendi, M. A. (2016). "The Power of Good Corporate Governance: Teori dan Implementasi ( $2^{\text {nd }}$ ed.)". Jakarta: Salemba Empat.

20. Eisenhardt, K. M. (1989). "Agency Theory: An Assessment and Review". Academy of Management Review, 1: 57-74.

21. Fama, E., Jensen, M. C., (1993). "Separation of Ownership and Control". Journal of Law and Economics, 26, 301-325.

22. Fatihudin, D., Jusni, \& Mochklas, M. (2018). "How to Measure Financial Performance". International Journal of Civil Engineering and Technology, 6(9), 553557.

23. Foote, J., Gaffney, N. and Evans, J. R. (2010). "Corporate Social Responsibility: Implication for Performance Excellence”. Total Quality Management. 21(8), 799-812.

24. Fosberg, R. H. (2004). "Agency Problems and Debt Financing: Leadership Structure Effects. Corporate Governance: The international Journal of Business in Society, 4(1), 31-38.

25. Friedman, M. (1970). “A Theoretical Framework for Monetary Analysis”. Journal of Political Economy, 78(2), 193-238.

26. Gallo, M. Á. (2005). "Independent Board Directors: How to Improve their Contribution to the Family Business". IESE Business School Discussion Paper (589).

27. Godfrey, P. C., Merrill, C. B., \& Hansen, J. M. (2009). "The Relationship between Corporate Social Responsibility and Shareholder Value: An Empirical Test of the Risk Management Hypothesis". Strategic Management Journal, 30(4), 425-445.

28. Goodstein, J., Gautam, K. and Boekar, W. (1994). "The Effect of Board Size and Diversity on Strategic Change". Strategic Management Journal, 15 (3), 241-250.

29. Goodwin, J., Seow, J. L. (2000). "Corporate Governance in Singapore: Perceptions of Investors, Directors and Auditors". Accounting and Business Review, 7(1), 39-68.

30. Graves, S. B., \& Waddock, S. A. (1994). "Institutional Owners and Corporate Social Performance”. Academy of Management Journal, 37, 1034-1046.

31. Haley, U. C. (1991). "Corporate Contributions as Managerial Masques: Reframing Corporate Contributions as Strategies to Influence Society". Journal of Management Studies, 28(5), 485-510.

32. Haniffa, R. and Hudaib, M. (2006). "Corporate Governance Structure and Performance of Malaysian Listed Companies". Journal of Business Finance and Accounting, 33(7/8), 1034-1062.

33. Harningsih, S., Agustin, H., \& Setiawan, M. A. (2019). "The eEffect of Financial Performance on Firm Value with CSR Disclosure and Dividend Policy as Moderation 
Variables". Ranah Research: Journal of Multidisciplinary Research and Development, $1(2), 199-209$

34. Hasan, M.M.; Habib, A. (2017). "Corporate Life Cycle, Organizational Financial Resources and Corporate Social Responsibility". J. Contemp. Account. Econ., 13, 2036.

35. Higgs, D., (2003). "Review of the Role and Effectiveness of Non-executive Directors". The Department of Trade and Industry, London.

36. Hu, Y., Chen, S., Shao, Y., \& Gao, S. (2018). "CSR and firm value: Evidence from China". Sustainability, 10(12), 4597.

37. Iqbal, N., Ahmad, N., Basheer, N. A., \& Nadeem, M. (2012). "Impact of Corporate Social Responsibility on Financial Performance of Corporations: Evidence from Pakistan". International Journal of Learning \& Development, 2(6), 107-118.

38. Jackling, B., \& Johl, S. (2009). "Board structure and firm performance: Evidence from India's top companies". Corporate Governance: An International Review, 17(4), 492509.

39. Jensen, M. C. (1993). "The Modern Industrial Revolution, Exit, and the Failure of Internal Control Systems". The Journal of Finance, 48(3), 831-880.

40. Jensen, M. C., \& Meckling, W. H. (1976). "Theory of the Firm: Managerial Behavior, Agency Costs and Ownership Structure". Journal of Financial Economics, 3(4), 305360.

41. Jensen, M. C., (1986). "Agency Costs of Free Cash Flow, Corporate Finance and Takeovers". The American Economic Review, 76(2), 323-329.

42. Johansen, T. R. (2016). "EU Regulation of Corporate Social and Environmental Reporting". Social and Environmental Accountability Journal, 36(1), 1-9.

43. Johnson, R. A., \& Greening, D. W. (1999). "The Effects of Corporate Governance and Institutional Ownership Types on Corporate Social Performance". Academy of Management Journal, 42, 564-576.

44. Kao, M.F., Hodgkinson, L. Jaafar, A., (2018). "Ownership Structure, Board of Directors and Firm Performance: Evidence from Taiwan". Corporate Governance: The International Journal of Business in Society, 19(1), 174-202.

45. Khan, A., Tanveer, T., \& Malik, U. (2017). "An Empirical Analysis of Corporate Governance and Firm Value: Evidence from KSE-100 Index". Accounting, 3(2), 119130.

46. Kiel, G. and Nicholson, G. (2003). "Board Composition and Corporate Performance: How the Australian Experience Informs Contrasting Theories of Corporate Governance". Corporate Governance: An International Review, 11 (3), 189-205.

47. Klein, A. (2002). "Audit Committee, Board of Director Characteristics, and Earnings Management". Journal of Accounting and Economics, 33 (3): 375-400. 
48. Kochhar, R., (1996). "Explaining Firm Financial Leverage: The Role of Agency Theory vs. Transaction Cost Economics”. Strategic Management Journal, 17, 713-728.

49. Kock, C. J., Santaló, J., \& Diestre, L. (2012). "Corporate Governance and the Environment: What Type of Governance Creates Greener Companies?’. Journal of Management Studies, 49, 492-514.

50. Kumar, N., \& Singh, J. P. (2013). "Effect of Board Size and Promoter Ownership on Firm Value: Some Empirical Findings from India”. Corporate Governance: The International Journal of Business in Society, 13(1), 88-98.

51. Le, T. V. and O'Brien, J. P. (2010). "Can Two Wrongs Make a Right? State Ownership and Debt in a Transition Economy". Journal of Management Studies, 47(7), 1297-1316.

52. Lipton, M., \& Lorsch, J. W. (1992). "A Modest Proposal for Improved Corporate Governance". The Business Lawyer, 59-77.

53. Elsayed, K. (2007). "Does CEO Duality Really Affect Corporate Performance?". Journal Compilation, 15(6), 1203-1214.

54. Margolis, J. D., \& Walsh, J. P. (2003). "Misery Loves Companies: Rethinking Social Initiatives by Business". Administrative Science Quarterly, 48(2), 268-305.

55. Marom, I. Y. (2006). "Toward a Unified Theory of the CSP-CFP Link". Journal of Business Ethics, 67, 191-200.

56. McWilliams, A., \& Siegel, D. (2000). Corporate Social Responsibility and Financial Performance: Correlation or Misspecification?'. Strategic Management Journal, 21(5), 603-609.

57. Miralles-Quirós, M., Miralles-Quirós, J., \& Redondo Hernández, J. (2019). "ESG Performance and Shareholder Value Creation in the Banking Industry: International Differences". Sustainability, 11(5).

58. Mizruchi, M and Stearns, L. (1994). "A Longitudinal Study of Borrowing by Large American Corporations”. Administrative Science Quarterly, 39, 118-140.

59. Modigliani, F., \& Miller, M. H. (1958). "The Cost of Capital, Corporation Finance and the Theory of Investment". The American Economic Review, 48(3), 261-297.

60. Monciardini, D. (2016). "The 'Coalition of the Unlikely' Driving the EU Regulatory Process of Non-Financial Reporting”. Social and Environmental Accountability Journal, 36(1), 76-89.

61. Mujahid, Mubeen and Abdullah, Arooj. (2014). "Impact of Corporate Social Responsibility on Firms Financial Performance and Shareholders Wealth". European Journal of Business and Management. 6(31), 181-187.

62. Mukhtaruddin, M., Ubaidillah, U., Dewi, K., Hakiki, A., \& Nopriyanto, N. (2019). "Good Corporate Governance, Corporate Social Responsibility, Firm Value, and Financial Performance as Moderating Variable". Indonesian Journal of Sustainability Accounting and Management, 3(1), 55-64. 
63. Muller, A., \& Kräussl, R. (2011). "The Value of Corporate Philanthropy during Times of Crisis: The Sense Giving Effect of Employee Involvement". Journal of Business Ethics, 103(2), 203-220.

64. Mura, R., (2007). "Firm performance: Do Non-executive Directors have Minds of their Own? Evidence from UK Panel Data". Financial Management, 36(3), 81-112.

65. Nazir, M., Haque, A., \& Ali, S. (2009). "Can Board Mechanism affect the Firm Value in Pakistan". Corporate Ownership and Control, 6(3), 308-317.

66. Nuswandari, C. (2009). "Pengaruh Corporate Governance Perception Index terhadap Kinerja Perusahaan pada Perusahaan yang Terdaftar di Bursa Efek Jakarta”. Jurnal Bisnis Dan Ekonomi, 16(2), 70-84.

67. Odoemelam, N., \& Okafor, R. G. (2018). “The Influence of Corporate Governance on Environmental Disclosure of Listed Non-Financial Firms in Nigeria". Indonesian Journal of Sustainability Accounting and Management, 2(1), 25-49.

68. Oh, W. Y., Chang, Y. K., \& Cheng, Z. (2016). "When CEO Career Horizon Problems Matter for Corporate Social Responsibility: The Moderating Roles of Industry-Level Discretion and Blockholder Ownership”. Journal of Business Ethics, 133, 279-291.

69. Olaroyeke, R.T and Nasieku, T. (2015). "Effect of Corporate Social Responsibility on Performance of Manufacturing Companies in Nigeria". International Journal of Current aAdvanced Research.4 (8), 228-233.

70. Orlitzky, M. (2001). "Does Firm Size Comfound the Relationship between Corporate Social Performance and Firm Financial Performance?". Journal of Business Ethics, 33(2), 167-180.

71. Palia, D., Ravid S., (2002). "The Role of Founders in Large Companies: Entrenchment or Valuable Human Capital?’. Unpublished Manuscript, Rutgers University.

72. Peasnell, K., Pope, P. and Young, S. (2000). "Accrual Management to Meet Earnings Targets: UK Evidence Pre and Post Cadbury". British Accounting Review, 32 (4), 41545.

73. Peng, M. W. (2004). "Outside Directors and Firm Performance during Institutional Transitions'”. Strategic Management Journal, 25(5), 453- 471.

74. Peng, M.W., Sun, S.L., Pinkham, B., Chen, H., (2009). "The Institution-Based View as a Third leg for a Strategy Tripod". Academy of Management Perspectives. 23(3), 6381.

75. Pfeffer, J., Salancik, G.R., (1978). "The External cControl of Organizations: A Resource Dependence Perspective”. New York: Harper \& Row.

76. Ramdani, D., van Witteloostuijn, A. (2010). “The Impact of Board Independence and CEO Duality on Firm Performance: a Quantile Regression Analysis for Indonesia, Malaysia, South Korea and Thailand". British Journal of Management, 21(3), 607-627. 
77. Ratih, S. (2011). "Pengaruh Good Corporate Governance terhadap Nilai Perusahaan dengan Kinerja Keuangan sebagai Variabel Intervening pada Perusahaan Peraih the Indonesia Most Trusted Company-CGPI”. Jurnal Kewirausahaan, 5(2), 18-24.

78. Retno, R. D., \& Priantinah, D. (2012). "Pengaruh Good Corporate Governance dan Pengungkapan Corporate Social Responsibility terhadap Nilai Perusahaan (Studi Empiris pada Perusahaan yang Terdaftar di Bursa Efek Indonesia Periode 2007-2010)”. Nominal, Barometer Riset Akuntansi Dan Manajemen, 1(2), 84-103.

79. Rouf, M. (2011). "The relationship between Corporate Governance and Value of the Firm in Developing Countries: Evidence from Bangladesh". The International Journal of Applied Economics and Finance, 5, 237-244.

80. Ruigrok, W., Peck, S.I. and Keller, H. (2006). "Board Characteristics and Involvement in Strategic Decision Making: Evidence from Swiss Companies". Journal of Management Studies, 43 (5), 1201-1226.

81. Sanda, A. U., Mikailu, A. S., \& Garba, T. (2010). "Corporate governance mechanisms and firms' financial performance in Nigeria". Afro-Asian Journal of Finance and Accounting, 2(1), 22-39.

82. Scholtens, B. (2008). "A Note on the Interaction between Corporate Social Responsibility and Financial Performance". Ecological Economics. 68(1-2), 46-55.

83. Scott, D. H. (2007). "Strengthening the Governance and Performance of State-Owned Financial Institutions" (Policy Research Working Paper No. 4321).

84. Seifert, B.; Morris, A.S.; Bartkus, R.B. (2004). "Having, Giving, and Getting: Slack Resources, Corporate Philanthropy, and Firm Financial Performance". Bus. Soc., 43, 135-161.

85. Sethi, S. P. (2005). "Investing in Socially Responsible Companies is a must for Public Pension Funds-because there is no Better Alternative”. Journal of Business Ethics, 56, 99-129.

86. Shleifer, A., \& Vishny, R. W. (1997). "A survey of corporate governance”. Journal of Finance, 52, 737-783.

87. Socoliuc, M., Grosu, V., Hlaciuc, E., \& Stanciu, S. (2018). "Analysis of Social Responsibility and Reporting Methods of Romanian Companies in the Countries of the European Union”. Sustainability, 10(12), 205-231.

88. Tang, J., (2017). "CEO Duality and Firm Performance: The Moderating Roles of other Executives and Blockholding Outside Directors". European Management Journal, 35(3), 362-372.

89. Thompson, P., \& Cowton, C. J. (2004). "Bringing the Environment into Bank Lending: Implications for Environmental Reporting”. The British Accounting Review, 36(2), 197218. 
90. Tobing, A., Arkeman, Y., Sanim, B., \& Nuryartono, N. (2013). "Pengaruh Penerapan Good Corporate Governance terhadap Tingkat Kesehatan dan Daya Saing di Perbankan Indonesia". Jurnal Manajemen Teknologi, 12(3), 298-318.

91. Trudel, R., \& Cotte, J. (2009). "Does it Pay to be Good?". MIT Sloan Management Review, 50(2), 61-82.

92. Tumewu, R. C., \& Alexander, S. (2014). "Pengaruh Penerapan Good Corporate Governance terhadap Profitabilitas Pada Perusahaan Perbankan yang Terdaftar di BEI Periode 2009-2013". Accountability, 3(1), 205-232.

93. Uyun, Q. (2016). "Pengaruh Good Corporate Governance Terhadap Kinerja Keuangan Perbankan Diukur dengan Nilai Eva Momentum”. Jurnal Akuntansi Unesa, 4(3), 112131.

94. Waddock, A.S.; Graves, B.S (1997). "Corporate Social Performance-Financial Performance Link". Int. J. Contemp. Hosp. Manag., 30, 2586-2602.

95. Widagdo, B., M. Jihadi, Y. B., Oky, E. S., \& Sanju, K. S. (2020). "Financial Ratio, Macro Economy, and Investment Risk on Sharia Stock Return". Journal of Asian Finance, Economics, and Business, 7(12), 919-926.

96. Windah, G. C., \& Andono, F. A. (2013). "Pengaruh Penerapan Corporate Governance terhadap Kinerja Keuangan Perusahaan Hasil Survei the Indonesian Institute Perception Governance (IICG) Periode 2008-2011”. Calyptra: Jurnal Ilmiah Mahasiswa Universitas Surabaya, 2(1), 1-20.

97. Xie, B., Davidson III, W.N. and DaDalt, P.J. (2003). "Earnings Management and Corporate Governance: The Role of the Board and the Audit Committee". Journal of Corporate Finance, 9 (3), 295-316. 